\title{
Financial Distress Analysis of Registered Insurance Companies in Indonesia Stock Exchange 2015-2019
}

\author{
Harjadi and Pardomuan Sihombing
}

\begin{abstract}
This study aims to analyze the insurance financial ratio such as underwriting ratio, loss ratio, investment yield ratio, liability to liquid asset ratio, net premium growth ratio, technical reserve ratio and risk based capital to potential financial distress. The population in this study were all insurance subsector companies listed on the Indonesia Stock Exchange for the period 2015 to 2019. The sampling technique used was the purposive sampling method so that a research sample of 10 companies was obtained. The data analysis technique used logistic regression analysis method. The results showed that the underwriting ratio, net premium growth ratio, and risk based capital had a significant and negative effect on the potential for financial distress. Loss ratio, liability to liquid asset ratio, and technical reserve ratio have a significant and positive effect on the potential for financial distress while the investment yield ratio has no significant effect in predicting the potential for financial distress.
\end{abstract}

Index Terms - insurance subsector, financial ratio, logistic regression, risk based capital, financial distress.

\section{INTRODUCTION}

Since January 1, 2016, the Financial Services Authority (OJK) has required insurance, pension funds and financial institutions to carry out risk management. One of the failures in managing risk will have an impact on the company's financial problems such as a decline in financial conditions (financial distress) which can then lead to bankruptcy of the company. Iskandar et al [1] explained that Insurance companies have a function to provide protection to the public against economic losses that may arise and offer opportunities to save and invest their money. As one of the public fundraising companies, insurance companies must be able to carry out risk management properly to prevent financial distress.

Financial distress analysis can be used to anticipate financial problems in the company as an Early Warning System. In Indonesia, the financial ratios of the Early Warning System method used for insurance companies have been regulated in the Statement of Financial Accounting Standards (PSAK).

Jiwasraya Insurance is an example of an insurance company that has financial problems. Jiwasraya Insurance experienced liquidity pressure so that the company's equity was recorded negative at IDR 23.92 trillion in September

Published on November 19, 2020.

Harjadi, Master of Management, Mercu Buana University, Jakarta, Indonesia.

(corresponding e-mail: ejaharjadi@ gmail.com)

Pardomuan Sihombing, Master of Management, Mercu Buana University, Jakarta, Indonesia.

(e-mail: pardomuan.sihombing ${ }^{\circledR}$ mercubuana.ac.id)
2019. President director of PT. Asuransi Jiwasraya (Persero), Hexana Tri Sasongko, explained that Jiwasraya needed funds of IDR 32.89 trillion to meet the solvency ratio or Risk Based Capital (RBC) of 120 percent required by the OJK. Pricing errors, careless investment, stock price engineering and liquidity pressure from Savings Plan products were the main causes of the decline in the financial condition of PT Asuransi Jiwasraya (Persero).

According to Sihombing [2] financial statements are a summary of the company's operations and results for a certain period of time. Financial reports provide information concerning the financial position, performance and changes in the financial position of a company. Cahyaningtyas et al [3] explained that financial statement analysis is a tool to determine the company's financial position and the results achieved in connection with the selection of company strategies that will be or have been implemented.

The financial ratio analysis for loss insurance companies is formulated in PSAK No. 28 concerning Accounting for General Insurance. The financial ratios contained in PSAK No. 28 consisting of solvency ratios, profitability ratios, liquidity ratios, premium stability ratios and technical ratios. In addition, measuring the financial health of insurance companies can also use Risk Based Capital (RBC) or Risk Based Minimum Capital (MMBR).

Research conducted by Dewi and Mahfudz [4] on general insurance companies listed on the Indonesia Stock Exchange for the period 2010-2014 found that Surplus Ratio, Firm Size, and RBC have a negative influence on the possibility of financial distress in general insurance companies in Indonesia. Meanwhile, the Incurred Loss Ratio, Liquidity Ratio and Premium Growth Ratio variables have a positive influence on the possibility of financial distress in general insurance companies in Indonesia.

Rofiudin et al [5] explained that the RBC and Surplus Ratio variables had no effect on Financial Solvency. The variables that have a positive effect on the financial solvency of Islamic life insurance companies in Indonesia are risk management costs, while the Liquidity Ratio and Premium Growth Ratio variables have a negative effect.

Another study conducted by Primayanti and Arfianto [6] regarding the financial distress of Islamic life insurance companies in Indonesia using the RBC proxy and the Altman Z Score as the dependent variable found that the Investment Performance variable affects the financial health of Islamic life insurance companies in Indonesia. Meanwhile, by using the RBC proxy, it is found that the variables Investment Performance, Liquidity Ratio and Incurred Loss Ratio partially affect the financial health of Islamic life insurance companies in Indonesia for the period 2010-2015. 


\section{LITERATURE REVIEW}

Desiyanti et al [7] explained that financial distress is an economic condition of a company that experiences an inability to pay short-term obligations. According to Platt and Platt [8] financial distress is the stage of a decline in financial conditions experienced by a company prior to bankruptcy or liquidation. According to Zamachsyari and Amanah [9] company performance is a reflection of the company's financial health, so that good company performance indicates that the company's financial condition is good and vice versa. Financial distress appears as a concept that describes financial difficulties as a problem faced by a company. Financial distress is an early stage before bankruptcy occurs.

According to Koderstani et al [10] the first step towards bankruptcy is latency, which is a condition where the expected return on assets continues to decline. The second stage is the shortage of cash flow, which states that the company is experiencing a shortage of cash so that it cannot fulfill its financial obligations. The third stage is financial distress, namely the condition of the company experiencing financial difficulties. If the company cannot handle this, the company will go bankrupt. Sormuen and Laitinen [11] explained that the stages of the financial distress process consist of 3 stages: (1) Early stage, which is the stage where a decrease in profitability is indicated on the financial statements, (2) Late stage, namely the stage where a decrease in profitability is indicated along with an increase in leverage in the financial statements, (3) The final stage is the stage where the indication of a decrease in profitability is accompanied by an increase in leverage and a decrease in liquidity in the financial statements.

The Early Warning System (EWS) is used by the NAIC (National Association of Insurance Commisioners) or the United States insurance company in measuring financial performance and assessing the health level of insurance companies. EWS provides an early warning of possible financial difficulties and insurance company operations in the future. Other countries outside the United States that implement this system make slight modifications to the ratios used according to needs.

EWS uses a test ratio that is applied to the insurance company's financial statements to measure the company's financial performance and capabilities. The EWS used in Indonesia has been regulated in the Statement of Financial Accounting Standards (PSAK). Financial ratio analysis for general insurance companies the formulas are prepared in PSAK No. 28 concerning Accounting for General Insurance. There are several ratios that are important to assess the financial condition of an insurance company according to PSAK No. 28, namely the profitability ratio as measured by the underwriting ratio, loss ratio and investment yield ratio. The liquidity ratio as measured by the liability to liquid asset ratio, the premium stability ratio as measured by the net premium growth ratio, the technical ratios as measured by the technical reserve ratio, and risk based capital. Based on literature review, this study compiles a framework for testing hypotheses and answering the problem formulations in this study.

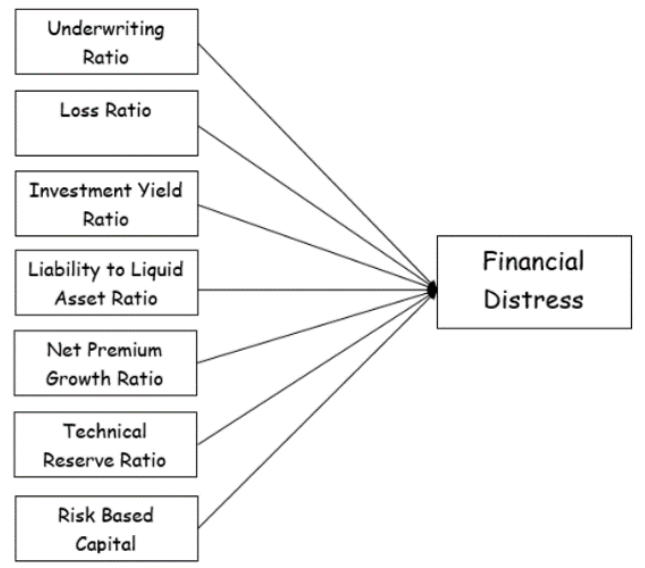

Fig. 1. Research Framework.

\section{RESEARCH METHODOLOGY}

This research is an associative study, which is research that aims to analyze the relationship and influence between two or more variables. This study aims to examine the effect of independent variables, namely Underwriting Ratio (UR), Loss Ratio (LR), Investment Yield Ratio (IYR), Liability to Liquid Asset Ratio (LLAR), Net Premium Growth Ratio (NPG), Technical Reserve Ratio (TRR) and Risk Based Capital (RBC) on the dependent variable, namely financial distress.

Sugiyono [12] explained that research variables are anything in the form that is determined by the researcher to study so that information is obtained about it, then conclusions are drawn. The dependent variable or dependent variable used in this study is financial distress, which is a dummy variable. The proxy used for financial distress in this study is Earning Per Share (EPS). EPS that has negative value will be symbolized by 1 which means the company is in a distress condition. Conversely, if the company has a positive EPS value, it will symbolize 0. According to Nurviani and Oetomo [13] companies that have negative EPS are categorized as distress companies, while companies that have positive EPS values are categorized as non-distress companies. This research is also supported by research by Ramdani and Wijaya [14] which uses the dependent variable EPS as a proxy for financial distress.

The population in this study were 10 publicly listed insurance companies on the Indonesia Stock Exchange for the period 2015-2019. The determination of the sample used in this study was based on the purposive sampling method, namely the sampling technique with certain considerations and criteria. The tests will be carried out using logistic regression analysis.

\section{Result AND Discussion}

This study uses the financial statements of insurance subsector companies that are consistently listed on the Indonesia Stock Exchange for the period 2015-2019. Following are the results of descriptive statistical analysis in this study. 
A. Descriptive Analysis Result

TABLE 1: DESCRIPTIVE ANALYSIS DESCRIPTIVE STATISTICS

\begin{tabular}{cccccc}
\hline & $\mathrm{N}$ & Minimum & Maximum & Mean & $\begin{array}{c}\text { Std. } \\
\text { Deviation }\end{array}$ \\
\hline EPS & 50 & -49.31 & 612 & 139.15 & 177.35 \\
UR & 50 & .00017 & 1.03 & .4123 & .26886 \\
LR & 50 & .26 & 2.42 & .8903 & .41680 \\
IYR & 50 & .18 & 1.50 & .9831 & .26569 \\
LLAR & 50 & .23 & .91 & .6965 & .16728 \\
NPG & 50 & -.30 & 2.17 & .0722 & .35188 \\
TRR & 50 & .77 & 6.51 & 1.8509 & 1.13909 \\
RBC & 50 & 1.28 & 9.14 & 3.1045 & 2.10300 \\
Valid N & 50 & & & & \\
(listwise) & 50 & & & & \\
\hline
\end{tabular}

The results of the descriptive statistical analysis in Table 1 show that the minimum value of EPS is -49.31 which was obtained by PT Asuransi Harta Aman Pratama Tbk in 2017. A negative EPS means that the net income owned by the company is negative. The highest EPS value is shown by PT Lippo General Insurance Tbk in 2017 with an EPS value 612. On average, insurance companies listed on the IDX have a positive EPS, which is 139.15 which means that the company's operational activities are able to generate profits from the business undertaken.

Underwriting Ratio shows a minimum value of 0.00017 obtained by PT Asuransi Bina Dana Arta Tbk in 2015 while a maximum value of 1.03 was obtained by PT Asuransi Dayin Mitra Tbk in 2018.This ratio shows the level of underwriting results obtained and is used to measure the profit level of insurance business so that this ratio is included in one of the company's profitability ratios. The higher the value of this ratio, the company will avoid financial distress. The mean value of 0.4123 shows that the industry average is able to generate profits from the business undertaken. If this ratio is negative, the premium rate charged is still too high.

Loss Ratio in Table 1 shows a minimum value of 0.26 and a maximum of 2.42. The higher the Loss Ratio, the greater the losses suffered by the insurance company. A good loss ratio value is below $100 \%$ or 1 . Investment Yield Ratio in this study shows a minimum value of 0.18 and a maximum of 1.5 . The higher this ratio, the better the insurance company's investment management.

The minimum liability to liquid asset ratio value occurs at PT Victoria Insurance Tbk in 2015 of 0.23 and the maximum value occurs at PT Asuransi Ramayana Tbk in 2016 of 0.91 . The positive mean value means that, on average, the insurance industry is still able to finance its short-term liabilities.

The minimum Net Premium Growth in this study was shown by PT Viktoria Insurance Tbk in 2018 of -0.30 , while the maximum value occurred in the same company in 2015 of 2.17. The mean and standard deviation of the NPG in this study were 0.0722 and 0.35188 , respectively. The mean value of 0.0722 indicates that each year the insurance industry continues to experience an increase in the amount of premium received. This is indicated by the positive mean NPG.
The Technical Reserve Ratio in Table 1 shows a minimum value of 0.77 obtained by PT Asuransi Ramayana Tbk in 2019. While the maximum value was obtained of 6.51 through PT Asuransi Dayin Mitra Tbk in 2015. This low ratio means that the company sets obligations technical is too low and if the company is not solvent, the company needs to make adjustments to the solvency margin.

In the descriptive statistical analysis, it shows that the RBC value of insurance companies listed on the Indonesia Stock Exchange 2015-2019 has a minimum value of 1.28 and a maximum of 9.14 with a mean of 3.1045 and a standard deviation of 2.103. This shows that according to RBC calculations, all insurance companies in this study can be categorized as solvent.

\section{B. Logistic Regression Result}

To assess the feasibility of the logistic regression model, a Goodness of Fit Test was used as measured by the ChiSquare value at the bottom of the Hosmer and Lemeshow test. The probability of significance obtained is then compared with a significance level of $5 \%$.

TABLE 2: HOSMER AND LEMESHOW TEST

\begin{tabular}{cccc}
\hline Statistic & $\begin{array}{c}\text { Chi- } \\
\text { square }\end{array}$ & DF & $\operatorname{Pr}>\mathrm{Chi}^{2}$ \\
\hline Hosmer-Lemeshow Statistic & 0.520 & 8 & 1.000 \\
\hline
\end{tabular}

Based on the results of the Hosmer and Lemeshow test in Table 2, it can be seen that the chi square value of 0.520 with a significance level of 1,000 is greater than the $\alpha$ level, namely $5 \%$ or a significance of $1>0.05$. Thus, the null hypothesis $\left(\mathrm{H}_{0}\right)$ is accepted and the research model is classified as fit or good and feasible in explaining the research variables namely Underwriting Ratio, Loss Ratio, Investment Yield Ratio, Liability to Liquid Assets Ratio, Net Premium Growth, Technical Reserve Ratio and Risk Based Capital against financial distress conditions in insurance companies.

According to Ghozali [15] the coefficient of determination is a test to measure the ability of the independent variable in explaining the dependent variable. The coefficient of determination in the logistic regression can be seen in the Nagelkerke R Square value. Nagelkerke R Square can be interpreted as the value of $R$ Square in multiple regression.

Based on the test results shown in Table 3, there is a Nagelkerke 'R Square value of 0.899 , which means that the variability of the dependent variable (financial distress) can be explained by the variability of the independent variable of $89.9 \%$, while $10.1 \%$ is explained by other variables outside of this study. This value also indicates that the independent variables taken in this study are quite good at explaining financial distress variables.

\begin{tabular}{cc} 
TABLE 3: COEFFICIENT DETERMINATION \\
\hline Statistic & Full \\
\hline-2 Log(Likelihood) & 26.383 \\
R $^{2}$ (McFadden) & 0.809 \\
R $^{2}$ (Cox and Snell) & 0.674 \\
R $^{2}$ (Nagelkerke) & 0.899
\end{tabular}


The odds ratio is a measure of the association of exposure (risk factor) with events to compare the likelihood of the expected occurrence of two different events.

\begin{tabular}{ccc}
\multicolumn{3}{c}{ TABLE 4: ODDS RATIO } \\
\hline Source & Value & Odds ratio \\
\hline Intercept & -17.759 & 0.00000 \\
UR & -11.943 & 0.00001 \\
LR & 4.187 & 65.79362 \\
IYR & -1.824 & 0.16143 \\
LLAR & 23.249 & $12,499,676,646$ \\
NPG & -17.481 & 0.00000 \\
TRR & 1.014 & 2.75727 \\
RBC & -1.913 & 0.14766 \\
\hline
\end{tabular}

The odds ratio value is obtained from the natural logarithm in the value column. The value in software interpretation $\mathrm{R}$ can be defined as the coefficient value of the variables in the model. The UR odds ratio value of 0.000001 means that if UR increases by 1 unit, the probability for minus EPS is 0.00001 times compared to positive or the greater the UR, the greater the probability of positive EPS.

The LR odds ratio value in table 5 is 65.79 , which means that if the LR increases by 1 unit, the probability for minus EPS is 65.79 times compared to positive or the greater the LR, the greater the probability of negative EPS. The IYR odds ratio shows a value of 0.16 and means that if the IYR increases by 1 unit, the probability for EPS minus is 0.16 times compared to positive or the greater the IYR, the more likely the EPS will be positive.

LLAR has the highest odds ratio value of 12,499,676,646 and means that if LLAR increases by 1 unit then the probability of minus EPS is $12,499,676,645$ times compared to positive or the greater LLAR, the greater the probability of negative EPS. The NPG odds ratio value is 0.000001 , which means that if the NPG increases by 1 unit, the probability for minus EPS is 0.000001 times compared to positive or the greater the NPG, the greater the probability of positive EPS.

The odds ratio value for TRR is 2,757 , which means that if TRR increases by 1 unit, the possibility for minus EPS is 2,757 times compared to positive or the greater the TRR, the greater the probability of negative EPS. The RBC odds ratio value is 0.15 , which means that if the RBC increases by 1 unit, the probability for minus EPS is 0.15 times compared to positive or the greater the RBC, the greater the probability of positive EPS.

Simultaneous test is used to see the effect of all independent or independent variables together on the dependent variable or dependent variable of a study. This study will use the simultaneous omnibus test with a significance level of $95 \%$ or an alpha of $5 \%$.

Table 5 shows that the significance value or symbolized by $\mathrm{Pr}$ in the model is $0.016<0.05$, which means rejecting $\mathrm{H}_{0}$ or there is a joint influence of the independent variables on the dependent variable. This also means that the variables UR, LR, IYR, LLAR, NPG, TRR and RBC have a simultaneous effect on the financial distress of insurance companies.
TABLE 5: OMNIBUST TEST

\begin{tabular}{ccc}
\hline Statistic & Chi-square & $\operatorname{Pr}>\mathrm{Chi}^{2}$ \\
\hline-2 Log (Likelihood) & 112.0867613 & $<0.0001$ \\
Score & 59.9735772 & $<0.0001$ \\
Wald & 10.25937352 & 0.016 \\
\hline
\end{tabular}

To find out which variables have a partial effect, a Wald test will be performed. The criterion for rejection of $\mathrm{H}_{0}$ is used if the value of the significant Wald Test is smaller than the alpha value (0.05). The following are the results of the Wald Test

TABLE 6: WALD TEST

\begin{tabular}{cccc}
\hline Source & Value & Wald Chi-Square & $\operatorname{Pr}>\mathrm{Chi}^{2}$ \\
\hline Intercept & -17.759 & 6.446 & 0.011 \\
UR & -11.943 & 10.018 & 0.002 \\
LR & 4.187 & 10.149 & 0.001 \\
IYR & -1.824 & 1.610 & 0.205 \\
LLAR & 23.249 & 8.893 & 0.003 \\
NPG & -17.481 & 9.961 & 0.002 \\
TRR & 1.014 & 8.712 & 0.003 \\
RBC & -1.913 & 8.956 & 0.003 \\
\hline
\end{tabular}

The UR variable shows a coefficient value of -11.943 with a Wald Chi Square of 10.018. The significance value of UR is 0.002 or <alpha (0.05) which means rejecting $\mathrm{H}_{0}$, it can be concluded that the UR variable has a partial effect on financial distress. The minus value on the coefficient shows that the UR variable has an opposite relationship to financial distress so that the higher the UR value, the smaller the potential for financial distress.

The LR variable shows a coefficient value of 4.187 with a Wald Chi Square of 10.149. The LR significance value is 0.001 or <alpha $(0.05)$ which means rejecting $\mathrm{H}_{0}$, it can be concluded that the LR variable has a partial effect on financial distress. A positive value on the coefficient indicates that the LR variable has a unidirectional relationship to financial distress so that the higher the LR value, the greater the potential for financial distress.

The IYR variable shows a coefficient value of -1.824 with a Wald Chi Square of 1.610. The IYR significance value is 0.205 or >alpha (0.05), which means accept $\mathrm{H}_{0}$, it can be concluded that the IYR variable has no partial effect on the financial distress of insurance companies.

The LLAR variable shows a coefficient value of 23.249 with a Wald Chi Square of 8.893. The LLAR significance value is 0.003 or <alpha (0.05), which means rejecting $\mathrm{H}_{0}$, it can be concluded that the LLAR variable has a partial effect on financial distress. A positive value on the coefficient indicates that the LLAR variable has a unidirectional relationship to financial distress so that the higher the LLAR value, the greater the potential for financial distress.

The NPG variable shows a coefficient value of -17.481 with a Wald Chi Square of 9.961. The NPG significance value is 0.002 or <alpha (0.05), which means rejecting $\mathrm{H}_{0}$, it can be concluded that the NPG variable has a partial effect on financial distress. The minus value on the coefficient shows that the NPG variable has an opposite relationship to financial distress so that the higher the NPG value, the smaller the potential for financial distress. 
The TRR variable shows a coefficient value of 1.014 with a Wald Chi Square of 8.712. The TRR significance value is 0.003 or <alpha (0.05) which means rejecting $\mathrm{H}_{0}$, it can be concluded that the TRR variable has a partial effect on financial distress. A positive value on the coefficient indicates that the TRR variable has a unidirectional relationship to financial distress so that the higher the TRR value, the greater the potential for financial distress.

The RBC variable shows a coefficient value of -1.913 with a Wald Chi Square of 8.956. The RBC significance value is 0.003 or <alpha (0.05), which means rejecting $\mathrm{H}_{0}$, it can be concluded that the RBC variable has a partial effect on financial distress. The minus value on the coefficient shows that the RBC variable has an opposite relationship to financial distress so that the higher the $\mathrm{RBC}$ value, the smaller the potential for financial distress.

\section{Discussion}

Based on the results of logistic regression testing, it can be found that the profitability ratio as measured by the underwriting ratio has a negative effect on the probability of financial distress. This is evidenced by the regression results at a significance value of $X_{1}$ greater than the alpha value $(\alpha=5 \%)$. This research is in line with research conducted by Fatmawati and Rihardjo [16] which found that the profitability ratio has a negative effect on the possibility of financial distress. In addition, there are also differences in the results of this study as conducted by Zelie [17] which explains that the profitability ratio has positive results on potential financial distress.

Logistic regression analysis shows that the profitability ratio as measured by the loss ratio has a positive effect on the probability of financial distress. This is evidenced by the regression results at a significance value of $\mathrm{X}_{2}$ greater than the alpha value $(\alpha=5 \%)$. This research is in line with research conducted by Dewi and Mahfudz [4] who found that the loss ratio has a positive effect on the possibility of financial distress in insurance companies. Research that does not support this result is shown by Deitiana [18] which shows that the loss ratio has no effect on the potential financial distress of insurance companies.

Based on the results of logistic regression testing, it can be found that the profitability ratio as measured by the investment yield ratio has no effect on the probability of financial distress. This is evidenced by the regression results at the significance value of $\mathrm{X}_{3}$ which is smaller than the alpha value $(\alpha=5 \%)$. This research is in line with the research conducted by Primayanti [6] who obtained the results that Investment Performance has no influence on the company's potential financial distress.

The logistic regression analysis results show that the liquidity ratio as measured by the Liability to Liquid Asset Ratio has a positive effect on the probability of financial distress. This is evidenced by the regression results at the significance value of $\mathrm{X}_{4}$ which is greater than the alpha value $(\alpha=5 \%)$. This research is in line with research conducted by Dewi and Mahfudz [4] which explains that the Liability to Liquid Asset Ratio has a positive influence on the possibility of financial distress in insurance companies. This research is also reinforced by Nurlatifah and Mardian [19] who obtained the results that the liquidity ratio has a negative effect on the financial performance of insurance companies.

Based on the results of logistic regression testing, it can be found that the premium stability ratio as measured by the net premium growth ratio has a negative effect on the probability of financial distress. This is evidenced by the regression results at the significance value of $\mathrm{X}_{5}$ which is greater than the alpha value $(\alpha=5 \%)$. This research is in line with research conducted by Deitiana [18] who found that the premium growth ratio has the opposite effect on the potential financial distress of insurance companies. This is also reinforced by Markonah et al [20] who got the results that premium growth has a positive influence on company performance. Other research that does not support this result is obtained from Dewi and Mahfudz [4] who found that premium growth has no effect on the potential financial distress of insurance companies.

The results of logistic regression analysis show that the technical ratio as measured by the Technical Reserve Ratio has a positive effect on the probability of financial distress. This is evidenced by the regression results at a significance value of $\mathrm{X}_{6}$ which is greater than the alpha value $(\alpha=5 \%)$. This ratio shows how far the technical liabilities formed by the insurance company are reflected in the investment. The low TRR ratio indicates the tendency that the estimated selfdependent claims are not supported by adequate funds, furthermore, unearned premiums are less reflected in company investment.

The logistic regression test results show that risk based capital affects the probability of financial distress. This is evidenced by the results of the regression at the significance value of $X_{7}$ which is greater than the alpha value $(\alpha=5 \%)$. The coefficient value shows a negative number, which means that the higher the risk-based capital, the insurance company will be more protected from financial distress.

\section{CONCLUSION}

Based on the results of the study, here are the conclusions obtained in this study (1) The results show that the profitability ratio as measured by the underwriting ratio has a negative effect on the probability of financial distress, (2) The results show that the profitability ratio as measured by the loss ratio has an effect positive on the probability of financial distress, (3) The results show that the profitability ratio as measured by the investment yield ratio has no effect on the probability of financial distress, (4) The results show that the liquidity ratio as measured by the Liability to Liquid Asset Ratio has a positive effect on the probability of financial distress, (5) Based on the research results, it can be found that the premium stability ratio as measured by the net premium growth ratio has a negative effect on the probability of financial distress, (6) The results show that the technical ratio as measured by Technical Reserve Ratio, has a positive effect on the probability of financial distress, (7) The results show that risk based capital has a negative effect on the probability of financial distress.

Based on the research results obtained, the following are suggestions put forward in this study (1) This study shows that the underwriting ratio, loss ratio, liability to liquid asset ratio, net premium growth, technical reserve ratio and risk 
based capital have an effect on the potential for financial distress. insurance company. This ratio can be an early warning system for management in analyzing financial distress in insurance companies, and (2) this study uses the insurance company's financial ratios. Further research can use non-financial ratios such as Good Corporate Governance and external factors such as inflation and Gross Domestic Product. Other studies can also use a sample of Islamic insurance companies and government insurance as research objects.

\section{REFERENCES}

[1] Iskandar, K., Fuad, M.N., Wirasadi, F dan Sendra, K. 2011. Dasar Dasar Asuransi : Jiwa, Kesehatan dan Anuitas. Asosiasi Ahli Manajemen Asuransi Indonesia (AAMAI). Jakarta.

[2] Sihombing, Pardomuan. 2018. Corporate Financial Management. Percetakan IPB. Jawa Barat.

[3] Cahyaningtyas, I., Sriwidodo, U dan Utami, S.S. 2016. “Analisis Financial Distress Menggunakan Model Altman Z-Score Pada Perusahaan Asuransi Yang Listing Di Bursa Efek Indonesia Tahun 2011 - 2014". Jurnal Ekonomi dan Kewirausahaan, Vol. 16 No. 2 , 287-293.

[4] Dewi, T.T.C and Mahfudz. 2016. "Effect of Change in Surplus Ratio, Incurred Loss Ratio, Liquidity Ratio, Premium Growth Ratio, Firm Size and Risk Based Capital to Predict The Posibilities of Financial Distress: The Case of Indonesian Non-Life Insurance Listed in Indonesia Insurance Directory". Diponegoro Journal of Management, Vol. 5 No. 3 e-ISSN 2337-3792, 1-17.

[5] Rofiudin, M., Masichah dan Afifudin. 2019. "Analisis Pengaruh Rasio Keuangan Risk Based Capital dan Early Warning System Terhadap Financial Solvency Pada Perusahaan Asuransi Jiwa Syariah di Indonesia". Jurnal E-JRA, Vol. 8 No. 3, 81-97.

[6] Primayanti, A and Arfianto, E.D. 2016. "The Determinant Of Financial Health On Sharia Life Insurance Company (Empirical Research on Sharia Life Insurance)". Diponegoro Journal of Management, Vol. 5 No. 3 e-ISSN 2337-3792, 1-14.

[7] Desiyanti, O., Soedarmono, W., Chandra, K and Kusnadi. 2019. "The Effect of Financial Ratios to Financial Distress Using Altman Z-Score Method in Real Estate Companies Listed in Indonesia Stock Exchange Period 2014 - 2018". Journal Business and Entrepreneurial, Vol. 19 No. 2 e-ISSN 2252-4614 p-ISSN 08539189, 119-136.

[8] Platt, H.D dan Platt M.B. 2002. "Predicting Corporate Financial Distress: Reflections on Choice-Based Sample Bias". Journal of Economics and Finance, Vol. 26 No. 2, 184-199.

[9] Zamachsyari, A.Z dan Amanah, L. 2016. "Pengaruh Kinerja Keuangan Dan Ukuran Perusahaan Terhadap Financial Distress”. Jurnal Ilmu dan Riset Akuntansi, Vol. 5 No. 11 ISSN 2460-0585, 115.

[10] Kordestani G., BIglari,V dan Bakhtiari, M. 2011. "Ability of Combination of Cash Flow Components to Predict Financial Distress". Bussiness: Theory and Practice, Vol.12 No.3 e-ISSN 18224202 p-ISSN 1648-0627, 277-285.

[11] Sormunen, N and Laitinen T. 2012. "Late Financial Distress Process Stage and Financial Ratios: Evidence for Auditors' Goingconcern Evaluation" Liketaloudelinen Aikakauskirja No.1, pp. 41-69.

[12] Sugiyono. 2018. Metode Penelitian Kuantitatif Kualitatif dan R\&D. Alfabeta. Bandung.

[13] Nurviani, D.I dan Oetomo, H.W. 2018. "Pengaruh Financial Leverage, Ukuran Perusahaan dan Arus Kas Terhadap Financial Distress Pada Perusahaan Property Dan Real Estate". Jurnal Ilmu dan Riset Manajemen, Vol. 7 No. 1 e-ISSN 2461-2593, 1-17.

[14] Ramdani, S dan Wijaya, I. 2019. "Prediksi Financial Distress Menggunakan Pertumbuhan Penjualan dan Corporate Governance Pada Perusahaan Sektor Pertambangan". Jurnal MONEX Vol. 8 No. 2 E-ISSN 2549-5046 P-ISSN 2089-5321, 34-45.

[15] Ghozali, Imam. 2018. Aplikasi Analisis Multivariate dengan Program IBM SPSS 25 Update PLS Regresi. Semarang: Badan Penerbit Universitas Diponegoro.

[16] Fatmawati, V dan Rihardjo, I.B. 2017. "Dampak Faktor Eksternal Dan Internal Pengaruh Likuiditas, Leverage, Aktivitas dan Profitabilitas Dalam Memprediksi Financial Distress". Jurnal Ilmu dan Riset Akuntansi, Vol. 6 No. 10 e-ISSN 2460-0585, 1-19.

[17] Zelie, E.M. 2019. "Determinants of Financial Distress in Case of Insurance Companies in Ethiopia”. Research Journal of Finance and
Accounting, Vol. 10 No. 15 e-ISSN 2222-2847 p-ISSN 2222-1697, 27-32.

[18] Deitiana, T. 2019. "Financial Early Warnings Signal on Stock Price Changes on Insurance Companies of Indonesian Stock Exchange". International Journal of Business, Economics and Law. Vol. 20 No. 1 ISSN 2289-1552, 22-26.

[19] Nurlatifah, A.F dan Mardian, S. 2016. "Kinerja Keuangan Perusahaan Asuransi Syariah di Indonesia: Surplus On Contribution (SOC)". Jurnal Ilmu Akuntansi, Vol. 9 No. 1 e-ISSN 2461-1190 p-ISSN 1979858X, 73-96.

[20] Markonah, Sudiro, A., Surachman and Rahayu, M. 2019. "The Effect of Corporate Governance and Premium Growth on the Performance of Insurance Companies in Indonesia”. European Research Studies Journal, Vol. 22 No. 2, 367-383. 